\title{
Pore resistivity variation by Resistivity imaging technique in sedimentary part of main Gadilam river basin, Cuddalore District, Tamil Nadu, India
}

R. Ravi*

Department of Earth Sciences, Annamalai University, Annamalai Nagar-608002 (Tamil Nadu), India

\section{S. Aravindan}

Department of Earth Sciences, Annamalai University, Annamalai Nagar-608002 (Tamil Nadu), India

\section{Ramachandran}

Department of Geology, Periyar University, Salem-636011 (Tamil Nadu), India

\section{Sanjay Kumar Balabantaray}

Department of Earth Sciences, Annamalai University, Annamalai Nagar-608002 (Tamil Nadu), India

\section{B. Selvaraj}

Department of Earth Sciences, Annamalai University, Annamalai Nagar-608002 (Tamil Nadu), India

\section{K. Santhakumar}

Department of Earth Sciences, Annamalai University, Annamalai Nagar-608002 (Tamil Nadu), India

*Corresponding author. Email: rajuravi9725@gmail.com

\section{Article Info}

https://doi.org/10.31018/

jans.v13i1.2541

Received: February 3, 2021

Revised: March 6, 2021

Accepted: March 10, 2021

\section{How to Cite}

Ravi, R. et al. (2021). Pore resistivity variation by Resistivity imaging technique in sedimentary part of main Gadilam river basin, Cuddalore District, Tamil Nadu, India. Journal of Applied and Natural Science, 13(1): 268 - 277. https://doi.org/10.31018/ jans.v13i1.2541

\begin{abstract}
Electrical resistivity is the only property of physics which give information of subsurface moisture content in the formation, Hence geophysical electrical resistivity survey was carried out to investigate the nature of shallow subsurface formations and geological contact in the main Gadilam river basin of Cuddalore District in Tamil Nadu. Twenty-seven vertical electrical soundings (VES) were conducted by Schlumberger configuration in the basin. Data is interpreted by curve matching techniques using IPI2 WIN software, layer parameters like apparent resistivity (pa) and thickness (h) interpretation were exported to Geographic Information System (GIS). Interpretation distinguishes three major geoelectric layers like topsoil, sandy clay layer, clayey sand layer along the contact zone in the basin. Interpreted VES sounding curves are mostly four-layer cases of $\mathrm{QH}, \mathrm{H}, \mathrm{HA}$ and KH type. Investigation demarcates lithology of subsurface and hydrogeological set up by employing maximum possible electrode sounding to infer saline water and freshwater occurrence based on resistivity signals. Zone of groundwater potential map was prepared with the combination of resistivity $(\rho=\rho 1+\rho 2+\rho 3+\rho 4)$ and corresponding thickness $(T=T 1+T 2+T 3+T 4)$. High resistivity value of $>200 \Omega \mathrm{m}$ and low resistivity value of $<10 \Omega \mathrm{m}$ show the occurrence of alkaline and saline water within the formation aquifers as a result of possible rock water interaction and saline water dissolution. Four-layer resistivity cases from the matched curve (namely $\mathrm{KH}, \mathrm{AH}, \mathrm{QA}$, and KA type) show the resistivity distribution/variation. It separates the freshwater depth wish from 1 to $140 \Omega \mathrm{m}$ in fluvial sediments. Flood basin, sandstone and clay layer with low resistivity value of $3.16-7.5 \Omega \mathrm{m}$ indicates contact with saline and freshwater aquifer. The Iso - resistivity map delineates saline water and freshwater zones with in the fourth layer cases in the same locations to indicate the irrational way of abstracting groundwater, resulting in saltwater ingress.
\end{abstract}

Keywords: GIS, Hydrogeology, Lithology, Resistivity, Saline water, Thickness - VES

\section{INTRODUCTION}

Geophysical resistivity investigations are performed for studies related to groundwater occurrence. Geophysics provides tools for studying earth interior by various physical properties depending on the method used (Oguama et al., 2019; Ibuot et al., 2017; Chakravarthi et al., 2007). The resistivity profile indicates horizontal 
change in resistivity, which can be compared with steeply dipping interface between two geological formations in the subsurface (Gautam and Biswas 2016; Biswas and Sharma 2016). The geo-electrical resistivity method (GERM) of geophysical prospecting has been utilized for several years for the resistivity discrimination of underlying litho units (George et al., 2017; Ekanem, 2020) and determines the resistivity of subsurface layers (including aquifer zones) at different depths in the event of low dipping (Prasanna et al., 2009). The occurrence of water and saline water of resistivity in the subsurface rock by electrical technique is widely applied to characterize the aquifer (Alile et al., 2011) and determine distinctive groundwater pollution (Ezeh 2011; Hussain et al., 2016a; Hussain et al., 2017). Early stage of geophysical studied for groundwater has been traced back to unconsolidated alluvial and semi-consolidated sedimentary tracts. Lately, greater significance is given to the investigation of subsurface water in hard rock and sedimentary regions, like the present study area (Deepa et al., 2016; Devaraj et al., 2018). The occurrence of pore water in subsurface soil, porosity and salinity of the water isused to delineate resistivity and its corresponding thickness in different layer/zones (Gopinath et al., 2015; Kayode et al., 2016; Mehmood et al. 2020). The advantage of applying resistivity method with different values of resistance in $\Omega \mathrm{m}$ is much larger than other geophysical properties (Kalinski et al. 1993). Various workers in coastal areas have used bulk resistivity value to show the contrast between saline filled formations saturated with freshwater (Ginsberg and Levanton, 1976; Frohlich et al. 1994). Saline water intrusion inthe coastal formation is a serious problem in most areas of world and occurs as an indicator for aquifer response (Custodio, 1997; Todd and Mays, 2005; Gopinath et al., 2015). By applying Schlumberger array in Curinor Korinbasin, southeast of Iran and area with high yield were identified through depth thickness and groundwater environment in the shallow aquifer (Lashkaripour, 2003; Nejad et al., 2012) investigated the subsurface layers and aquifer characteristics of the same area. Demarcation of the groundwater potential and recharge zones in Champavathi river basin, India, using electrical resistivity methods and identified high porosity and permeability zone using secondary resistivity parameters (Jagadeeswara Rao et al., 2003). Effective use of VES was vertical and horizontal section utilizing Schlumberger and Wenner array was attempted by (Al-Amri, 1996) in central Arabian shield for groundwater prospecting and delineating shallow alluvial aquifer and fracture zone as groundwater potential zones. VES surveys were also conducted in shale for the evaluation of resistivity and depth to basement by resistivity method inthe combination of iso-apparent resistivity to classify freshwater and saltwater of the basin (Balasubramanian et al., 1985; Kopsiaftis et al.,

\section{9).}

Sedimentary part of main Gadilam River basin, the study featured in the Cuddalore district, Tamil Nadu, due to development, expanding industrialization and through agriculture has resulted in decline water level and saline ingresses aquifers. In the majority of the basin, subsurface water is the only alternative to fulfil the agriculture, domestic and industrial demand of water. The main objective of the study was to infer geophysical electrical resistivity layer parameter and its thickness with the above data psudo cross section is constructed to infer vertical variation of resistivity as layer section in VES profile. Four layer resistivity cases were mapped spatially to study the variation of resistivity with reference to geology in space.

\section{MATERIALS AND METHODS}

\section{Study area}

Part of the Gadilam river basin forms a total length of about $57 \mathrm{~km}$ in the Kallakriuchiand Cuddalore districts of Tamil Nadu, India. It lies between $11^{\circ} 37^{\prime} 42.51^{\prime \prime} \mathrm{N}$ and $11^{\circ} 49^{\prime} 46.52^{\prime \prime} \mathrm{N}$ latitudes and $79^{\circ} 20^{\prime} 44.54^{\prime \prime} \mathrm{E}$ and $79^{\circ}$ 47'22.21"E longitudes (Fig. 1). It occurs within the Survey of India topographic sheets of $58 \mathrm{M} / 5,6,9,13,10$ and 14 , covering a total area ina plain portion of about $663.65 \mathrm{~km}^{2}$. The study areas altitude occurs from 109 $\mathrm{m}$ AMSL in south to $-4 \mathrm{~m} \mathrm{BMSL}$ in the east.

\section{Geological settings of Gadilam river basin}

Two geologic formations, namely Tertiary CuddaloreSandstones, Laterite and Quaternary Alluvial formations are found to prevail in the basin. It is characterized by both Archean crystalline aquifers and Tertiary Quaternary sedimentary rocks. The lithology of the basin shows that hard basement rocks are exposed in the western part of the study area and sedimentary formation in the east with a faulted contact between both (Aravindan et al., 2004). The Ponnaiyar River (Main river of Gadilam) is bounded in the northern part of Gadilam basin and in south by Neyveli Tertiary upland and confluences in the Bay of Bengal at Devanampatinam, East of Cuddalore. Since the accessibility of surfaces water is insufficient during the lean period, the demand for irrigation in the Gadilam river basin is met by substantial development of groundwater. The topography of the basin is flat and slopes towards the north northeast with maximum altitude of $40 \mathrm{~m}$ along the southeastern part of the study area. The area lies intropical and humid climate with a temperature of maximum range between 36.5 and $36.9^{\circ} \mathrm{C}$ with mean ranging from 31.0 to $37.5^{\circ} \mathrm{C}$. The study area is occupied by Pliocene deposits receives precipitation with the influence of southwest and northeast monsoons (CGWB 2015). The annual average rainfall in the basin is about $1,085 \mathrm{~mm} /$ year from northeast and southwest monsoon 


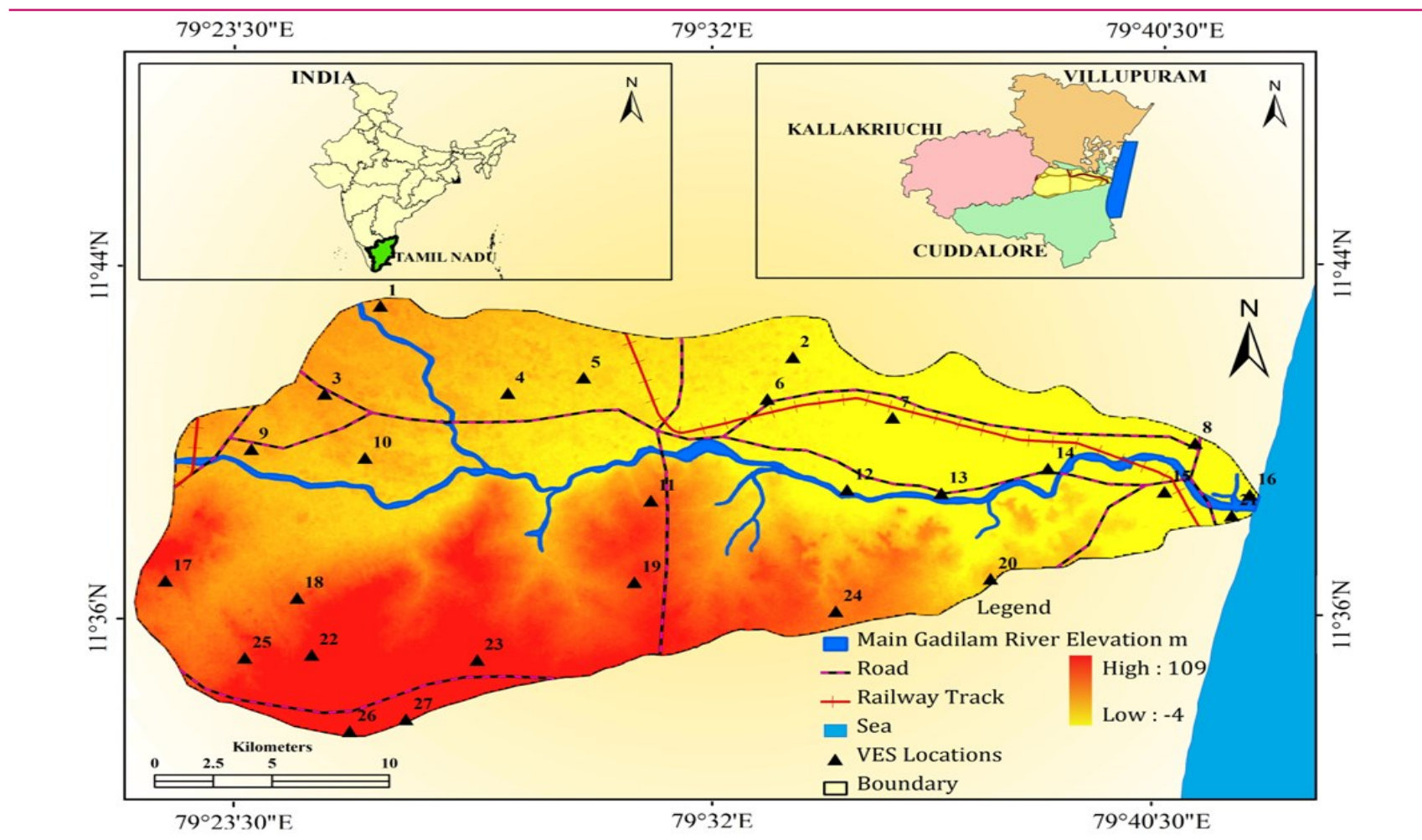

Fig. 1. Location, VES soundings and Elevation of the Gadilam river basin.

season, contributes $58 \%$ and $31.71 \%$, respectively. To the study area south, includes two large open cast mines (I and II), one small (Mine IA) lignite mines and its associated industries, including two thermal power plants that are operated by NLIL (Neyveli Lignite India Limited), a government of India public sector undertaking. The important large scale groundwater extraction corporations in this basin are NLIL and Small Industrial Promotion Corporation of Tamil Nadu (SIPCOT) complexes south of Cuddalore port south-east of study area are the major industries that prevails for maximum and domestic consumption requirement in the basin. EID parry sugar factory is located within the basin at Nellikuppam west of Cuddalore in the east of basin.

\section{Litho-stratigraphy and hydrogeology}

The present area is underlined by various geological formations; throughout the course of river Gadilam encounters different rock types and formations (Table 1 and Fig. 2). Gadilam river originates from the hard rock region situated in the west and passes through the hornblende-biotite gneiss, Tertiary CuddaloreSandstone formation and Quaternary formation in sedimentary part, which includes alluvial plain deposits, argillaceous sandstone, clay with limestone bands/ lenses, fluvial deposits, sandy limestone, laterite and deltaic plain includes palaeo tidal flat deposit with clays, sands and beach ridges of grey-brown sand (Subramanian and Selvan 2001). Geological details were investigated during field work by using projected geological map of Cuddalore district, published by Geological Society of India. At some locations, sandstone is found intercalated within lenses of clay and underlined by fluvial sand with a depth ranging below the ground from 2 and $22 \mathrm{~m}$ from Azhagappasamudram are isolated at depths from $22-50 \mathrm{~m}$ investigated in field work. Flood plain, fluvial and tidal flat deposits cover mostly in the east. The aquifers occur in Cuddalore sandstone and alluvium to study the saline - freshwater interface, which ultimately is helpful for the scientific development of both shallow and deeper aquifer in this area which is good potentiality.

Table 1. Litho-stratigraphy of Gadilam river basin (after Subramanian et al., 2001).

\begin{tabular}{llll}
\hline Period & Epoch & Formation & Lithology \\
\hline Quaternary & Recent to Sub recent & $\begin{array}{l}\text { Alluvium and } \\
\text { laterite }\end{array}$ & $\begin{array}{l}\text { Soils, Alluvium and Brown Sand, Clays and laterite } \\
\text { Tertiary }\end{array}$ \\
Mio-Pliocene & $\begin{array}{l}\text { Cuddalore - } \\
\text { Sandstones }\end{array}$ & $\begin{array}{l}\text { Argillaceous and Calcareous Sandstone, Clay with Lime- } \\
\text { stone bands/lenses, Lignite, Hornblende -biotite gneiss } \\
\text { and Sandy Limestone, Tidal flat deposit }\end{array}$ \\
\hline
\end{tabular}




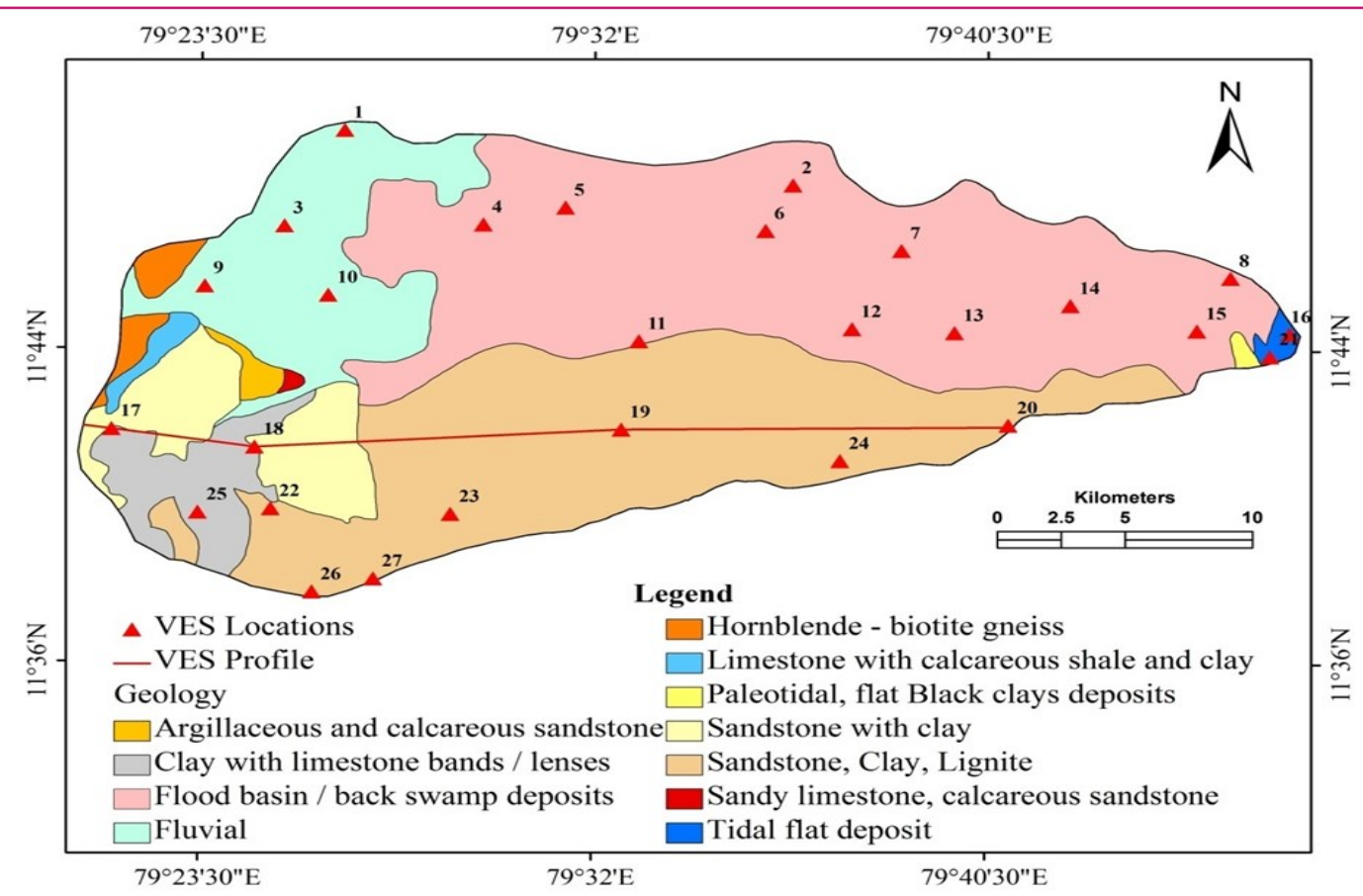

Fig. 2. Geology and VES Profile-cross section of the Gadilam river basin.

\section{Data acquisition and interpretation}

Twenty seven (27) Vertical Electrical Sounding (VES) locations havebeen carried out in the basin using DDR3 resistivity meter by applying Schlumberger array configuration (Fig. 1). The apparent resistivity of subsurface formation was determined. An investigation was conductedby placing four electrodes in a line. A known current is passed through the two extreme electrodes. Electro Motive Force (EMF) measured within two potential electrodes measure the potential difference of the ground. Apparent resistivity arrived by applying the formulae.

$\rho \mathrm{a}=\mathrm{KR}$,

Where, $\mathrm{K}$ is geometric factor,

$R$ is ground resistance of the depth and

is the apparent resistance measured, which depends on the current electrode $(A B)$ andpotential electrodes (MN) and its configuration as.

$\rho_{\mathrm{a}}=\frac{\pi\left(\left(\frac{\mathrm{AB}}{2}\right)^{2}-\left(\frac{\mathrm{MN}}{2}\right)^{2}\right)}{\mathrm{MN}}\left(\frac{\Delta \mathrm{V}}{\mathrm{I}}\right)$

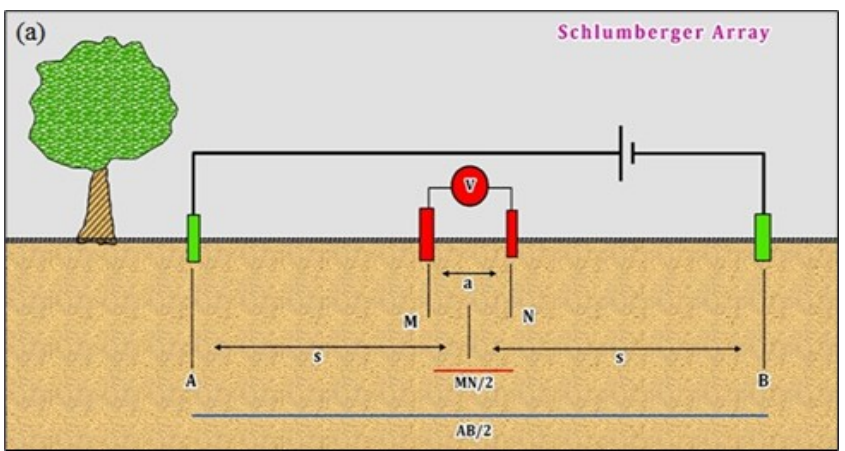

The minimum and maximum electrode spacing adopted for the present study with maximum current electrode $(A B / 2)$ spacing of $100 \mathrm{~m}$ across the area distance varying from 1 and $150 \mathrm{~m}$, and the potential electrode (MN/2) spacing varies from 0.5 to $15 \mathrm{~m}$, respectively.

Where, $a$ is the selected electrode spacing, $\Delta \mathrm{V}$ is the potential difference displayed between two central electrodes and

I is current passed into the ground through two outer electrodes and measured simultaneously with a potential difference.

Apparent resistivity values measured at each point attributes were plotted against electrode spacing (a) on bi -logarithmic graph sheets (Fig. 3). Curves were observed for the number and nature of layering by curve matching technique was performed for the quantitative interpretation of curves. Output curve matching (layer resistivities and thickness) was input in the system to model in an iterative modeling tool utilizing IPI2 WIN version 3.0.1.e (Bobachev et al. 2003). The degree of uncertainty of the computed model parameters and

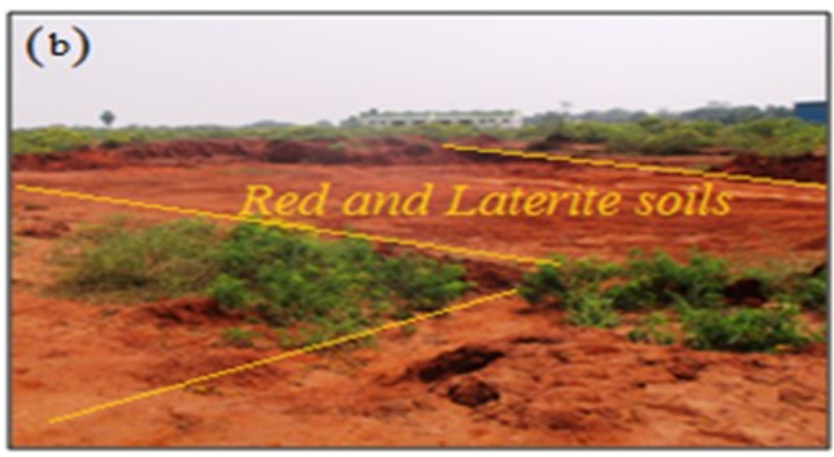

Fig. 3. a). Schlumberger configuration, b). lateritic soil outcrop and the mining site at Visur RF. 
Ravi, R. et al. / J. Appl. \& Nat. Sci. 13(1): 268 - 277 (2021)

\begin{tabular}{|c|c|c|c|c|c|c|c|c|c|c|c|}
\hline \multirow{2}{*}{$\begin{array}{l}\text { VES } \\
\text { No. }\end{array}$} & \multirow{2}{*}{ Location Name } & \multicolumn{3}{|c|}{ Resistivity $(\Omega m)$} & \multicolumn{5}{|c|}{ Thickness (m) } & \multirow[b]{2}{*}{$\begin{array}{l}\text { Error } \\
\%\end{array}$} & \multirow[b]{2}{*}{$\begin{array}{l}\text { Curve } \\
\text { Type }\end{array}$} \\
\hline & & $\rho 1$ & $\rho 2$ & $\rho 3$ & р4 & h1 & h2 & h3 & h4 & & \\
\hline 1 & Poigai Arasur & 51.6 & 24.6 & 3.2 & 14.1 & 0.86 & 2.53 & 2.31 & 103 & 8.12 & $\mathrm{H}$ \\
\hline 2 & Chinna pagandai & 19.1 & 97 & 8.39 & 59.8 & 0.318 & 0.449 & 0.795 & 1.89 & 3.18 & $\mathrm{QH}$ \\
\hline 3 & Karuveppilaipalayam & 47.6 & 10.6 & 2.81 & 167 & 0.851 & 11.3 & 13.9 & - & 3.21 & $\mathrm{QH}$ \\
\hline 4 & Rayappalaiyam & 16 & 83.9 & 11 & 158 & 0.294 & 0.469 & 1.02 & 3.38 & 3.42 & $\mathrm{QH}$ \\
\hline 5 & Ammapetai & 38.7 & 137 & 20.8 & 38 & 0.351 & 0.485 & 6.12 & 7.14 & 3.42 & $\mathrm{QH}$ \\
\hline 6 & Mel kavarapattu & 56.5 & 14.3 & 5.09 & 1326 & 0.699 & 3.68 & 44.2 & - & 3.36 & $\mathrm{H}$ \\
\hline 7 & Vazhapattu & 14 & 23.6 & 12.9 & 3144 & 0.635 & 4.03 & 98 & - & 7.82 & $\mathrm{HA}$ \\
\hline 8 & Manjakkuppam & 42.1 & 507 & 7.03 & 2217 & 1.61 & 2.48 & 53.7 & - & 4.04 & $\mathrm{KA}$ \\
\hline 9 & Thirunamanallur & 29.3 & 5.73 & 8.47 & 457 & 0.576 & 2.84 & 43.6 & - & 3.19 & $A$ \\
\hline 10 & Sivapatinam & 18.35 & 7.345 & 2.105 & 4.982 & 0.6547 & 6.006 & 6.251 & 28.77 & 1.00 & $\mathrm{AH}$ \\
\hline 11 & Panikankuppam & 57.6 & 2476 & 141 & 349 & 0.335 & 0.512 & 22.9 & 28.4 & 6.4 & $Q$ \\
\hline 12 & Sanniyasipettai & 70 & 21.1 & 91.9 & 12.9 & 1.19 & 0.971 & 2.9 & 38.8 & 2.71 & $\mathrm{QH}$ \\
\hline 13 & Kil Arungunam & 39.8 & 2.15 & 22.7 & 4.6 & 0.792 & 1.01 & 1.6 & 32.8 & 5.77 & $\mathrm{QH}$ \\
\hline 14 & Tiruvandipuram & 24.1 & 4.95 & 347 & 2.99 & 0.977 & 1.05 & 3.11 & 7.57 & 7.53 & $\mathrm{HA}$ \\
\hline 15 & Tiruppappuliyur & 17.3 & 1.21 & 0.271 & 579 & 0.42 & 1.17 & 2 & - & 4.97 & $\mathrm{HA}$ \\
\hline 16 & Vanniyarpalaiyam & 47.1 & 13.2 & 3.42 & 1047 & 0.44 & 19.1 & 16 & - & 8.47 & $\mathrm{HA}$ \\
\hline 17 & Arinattam & 107 & 1997 & 33.5 & 2938 & 1.74 & 1.65 & 85.8 & - & 3.74 & $\mathrm{KH}$ \\
\hline 18 & Olaiyampalayam & 24.1 & 6.475 & 83.99 & 6.077 & 0.6 & 0.7416 & 1.658 & 14.37 & 1.6 & $\mathrm{AH}$ \\
\hline 19 & Nadu Kattuppalaiyam & 55.6 & 17.6 & 1585 & 258 & 1.2 & 73.4 & - & - & 6.4 & QA \\
\hline 20 & Vellakarai & 31.9 & 2533 & 96.4 & 6.47 & 0.359 & 0.709 & 28.7 & 28.4 & 8.85 & $\mathrm{KA}$ \\
\hline 21 & Chellankuppam & 38.3 & 4.28 & 2.71 & 1048 & 1.32 & 4.09 & 26.9 & - & 2.77 & $\mathrm{H}$ \\
\hline 22 & $\begin{array}{l}\text { Chinna Odappank- } \\
\text { uppam }\end{array}$ & 119 & 10.4 & 39.7 & 887 & 1.71 & 8.81 & 85.8 & - & 2.95 & $\mathrm{QH}$ \\
\hline 23 & Perperiyankuppam & 112 & 1840 & 11.8 & 39774 & 3.7 & 2.08 & 5.85 & 9.43 & 8.48 & $\mathrm{KH}$ \\
\hline 24 & Arachchikkuppam & 35.5 & 1666 & 6.57 & 72.4 & 0.363 & 0.83 & 4.35 & 26.2 & 6.54 & $\mathrm{KQ}$ \\
\hline 25 & Pudupettai & 24 & 17.2 & 3.73 & 11.7 & 0.744 & 3.46 & 5.63 & 55.1 & 4.98 & $\mathrm{H}$ \\
\hline 26 & Vadakkirupu & 35.6 & 720 & 8.32 & 626 & 0.334 & 0.592 & 2.53 & - & 7.19 & $\mathrm{KH}$ \\
\hline 27 & Kattukodalur & 81 & 491 & 98.3 & 15.1 & 0.388 & 0.326 & 12.4 & 11.8 & 6.68 & QA \\
\hline
\end{tabular}

goodness of fit in the curve matching algorithm is expressed in terms of curve fitting with error $<10$. Resistivity of different layers and respective depth, thickness are displayed by many inversions in the model of all VES curves and resolved with the fitting error. These results were inputted in the GIS platform; their attributes were added and analyzed in Arc/GIS version 10.5 software in spatial analyst tool usedto map interpolation.

\section{RESULTS AND DISCUSSION}

The VES data values were interpreted and processed for the resistivity, thickness and curve types of different subsurface layers for geoelectrical-lithological layers with maximum current separation (Table 2) (Bethrand Ekwundu Oguama et al., 2020; Eyankware et al., 2020; Sholichin and Tri Budi Prayogo, 2019). 1D data version give information along with designated profiles and the depth (Waswa et al. 2015). The curve types obtained after partial curve matching range from simple 4-layers KH type (11.11\%), 6-layer HA type (14.81\%), 3-layer QA type $(3.70 \%)$ and 5-layer KA type (7.41\%). Curves generated from the field measurements are shown in (Table 2,3 and Fig. 4) the inferred geoelectric-lithology interpretation (Bayewu et al., 2018).

\section{Vertical electrical sounding (VES)}

The VES data was hand plotted in the field as a reference while performing curve matching technique for 
verification in IPI2 WIN software (Table 2). Higher resistivity of $39774 \Omega \mathrm{m}$ was observed in Perperiyankuppam to infer it as laterite in the southern part of the basin. The low resistivity value of $0.27 \Omega \mathrm{m}$ was confined to Tiruppappuliyur to interpret as marine clay inand around Cuddalore in the eastern part of the ba$\sin$.

$$
\text { Curve }=\frac{\text { Total resistivity layer thickness }}{\text { Total number of resistivity sounding }} \times 100
$$

From the data (Table 3 ) $25.93 \%$ of the basin is dominated by $\mathrm{QH}$ type curve indicating $\rho 1>\rho 2>\rho 3>\rho 4>\rho 5>\rho 6<\rho 7,14.81 \%$ of the area represent descending-ascending $\mathrm{H}$ type indicating $\rho 1>\rho 2<\rho 3>\rho 4$ and $14.81 \%$ by $\mathrm{HA}$ type indicating $\rho 1>\rho 2<\rho 3<\rho 4,11.11 \%$ of the basin is $\mathrm{KH}$ type indicating $\rho 1<\rho 2<\rho 3,7.41 \%$ by $\mathrm{KA}, \mathrm{AH}$ and $\mathrm{QA}$ types curve $\rho 1<\rho 2, \rho 1<\rho 2$, and $\rho 1>\rho 2$ and $3.70 \%$ by $A, Q$ and $K Q$ type curve as $\rho 1<\rho 2, \rho 1>\rho 2$ and $\rho 1<\rho 2$ types, respectively. Curve types reveal alternate resistive-low resistivity and low resistivity-high resistive layers reflecting the unconsolidated formations as sand and clay with alternate high to low resistivity sub surface layer of study area.

\section{Geoelectrical and pseudo cross sections 1D}

Resistivity pseudo cross section along (Fig. 4) which encompasses locations (Arinattam, Olaiyampalayam, Nadu Kattuppalaiyam and Vellakarai) was compared with resistivity values obtained from the inversion of

Table 3. VES curve types for various VES locations in the Gadilam river basin.

\begin{tabular}{ll}
\hline Curves types & No of VES curves \\
\hline $\mathrm{H}$ & $1,6,21,25$ \\
$\mathrm{QH}$ & $2,3,4,5,12,13,22$ \\
$\mathrm{HA}$ & $7,14,15,16$ \\
$\mathrm{KA}$ & 8,20 \\
$\mathrm{~A}$ & 9 \\
$\mathrm{AH}$ & 10,18 \\
$\mathrm{Q}$ & 11 \\
$\mathrm{KH}$ & $17,23,26$ \\
$\mathrm{QA}$ & 19,27 \\
$\mathrm{KQ}$ & 24 \\
\hline
\end{tabular}

VES as a 1D layered model. Resistivity of the pseudo cross section ranged between 13.9 and $193 \Omega \mathrm{m}$ occur irrespective of depth. Higher resistivity ranges were observed in location Olaiyampalayam up to a depth of 20 to $40 \mathrm{~m}$ and extending laterally up to Nadu Kattuppalaiyam. Depth between 1 to 4 and 13.9 to $60 \mathrm{~m}$, electrical resistivity values occur between 13.9 and $37.3 \Omega \mathrm{m}$ indicate the saline nature of formation (Zohdy et al. 1974; Gopinath et al. 2018) and found to extend up to Vellakarai. Low resistivity values at Nadu Kattuppalaiyam irrespective of depth indicated the overdrafting of groundwater from the aquifers, which might trigger saline water up to shallow depths.

\section{Spatial variation of resistivity and thickness}

The resistivity of the first layer-topsoil range from 14 to $119 \Omega \mathrm{m}$ was observed at Vazhapattu a low resistivity indicate sand saturated with water and Chinna Odappankuppam has high resistivity, with thickness between 0.29 and $3.70 \mathrm{~m}$ as observed in Rayarppalaiyam and Perperiyankuppam. It may be dry topsoil with less porosity and low permeability in this formation. The Southwestern part of the study area is represented by the poor conductive (100 to $200 \Omega \mathrm{m}$ ) high resistivity zone to indicate sandstone and hornblende biotite gneiss. A good conductive low resistivity range indicates the sedimentary rocks (Fig. 5a). A second layer, resistivity values from 1.21 to $2533 \Omega \mathrm{m}$ was observed up to above high resistivity zones; low resistivity zones occur at Vellakarai and Tiruppappuliyur with a thickness ranging from 0.33 and $73.40 \mathrm{~m}$ observed at Kattukodalur and Nadu Kattuppalaiyam were lithology layer of flood basin, sandstone and clay occur in north and southern part of the basin. In (Fig. 5b), low resistivity values from less than 10 to $100 \Omega \mathrm{m}$ occurr in the northwestern, south and eastern part of the basin in fluvial, flood basin, clay with limestone, sandstone, sandy limestone, paleotidal and tidal flat deposits from sedimentary rocks in the northwestern part near the hard rock contact to the southeastern part with saline and freshwater interface in the formation. Third layer resistivity value from 0.27 to $1585 \Omega \mathrm{m}$ was observed at Tiruppappuliyur, low resistivity at Nadu kattuppalaiyam and high resistivity with a thickness ranging from 0.80 to $98 \mathrm{~m}$ was observed in Chinna pagandai and Vazhapattu. The good conductive low resistivities indicated sedimentary rock underlined by fluvial, paleotidal and tidal flat deposit,

Table 4. Minimum, Maximum and Average value of resistivity $(\Omega \mathrm{m})$ and thickness $(\mathrm{m})$ of Gadilam river basin.

\begin{tabular}{lllllllll}
\hline & \multicolumn{3}{c}{ Resistivity $(\mathbf{\Omega m})$} & \multicolumn{4}{c}{ Thickness $(\mathbf{m})$} \\
\hline Min & Layer $\mathbf{1}$ & Layer $\mathbf{2}$ & Layer $\mathbf{3}$ & Layer 4 & Layer 1 & Layer 2 & Layer 3 & Layer 4 \\
Max & 14.00 & 1.21 & 0.27 & 2.99 & 0.29 & 0.33 & 0.80 & 1.89 \\
Average & 119.00 & 2533.00 & 1585.00 & 39774.00 & 3.70 & 73.40 & 98.00 & 103.00 \\
\hline
\end{tabular}




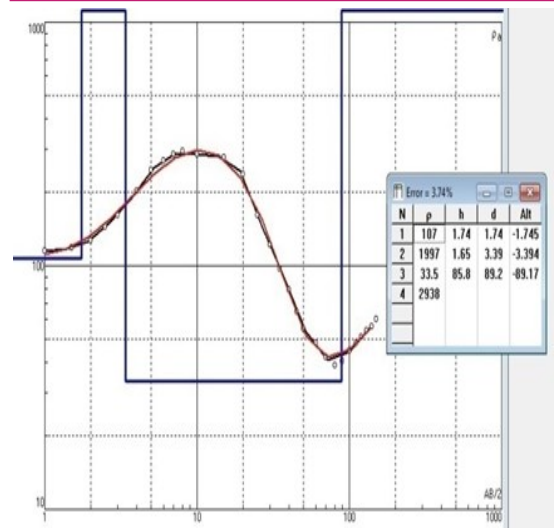

KH type curve at Arinattam

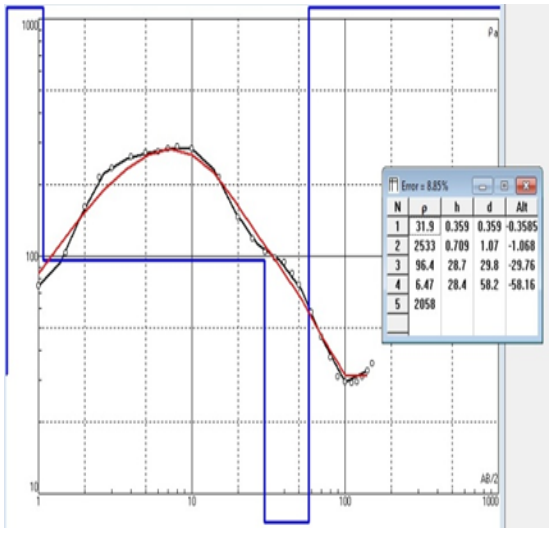

KA type curve at Vellakarai

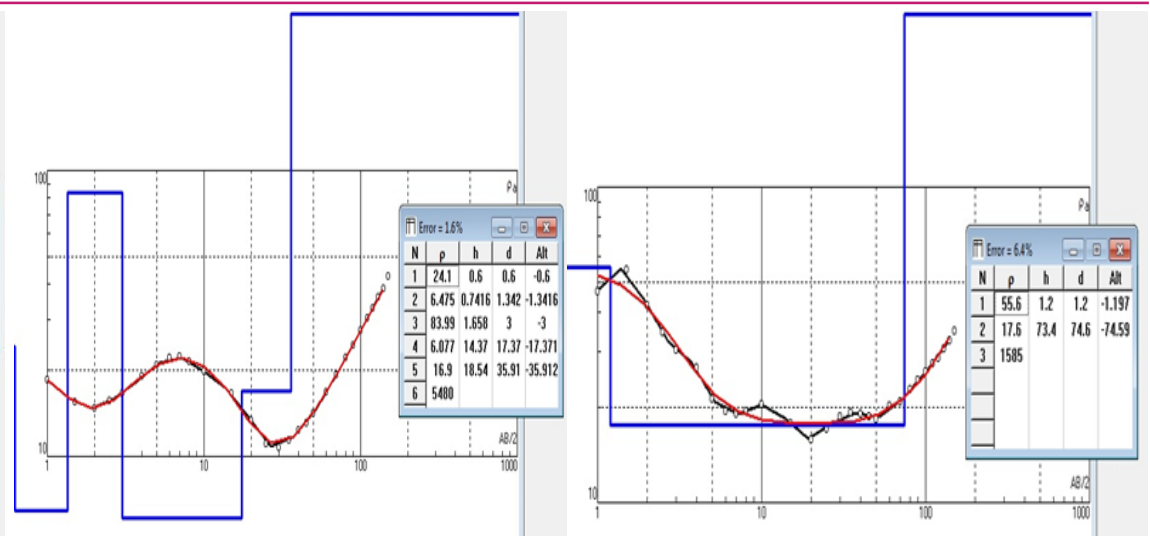

HA type curve at Olaiyampalayam

QA type curve at Nadu Kattuppalaiyam

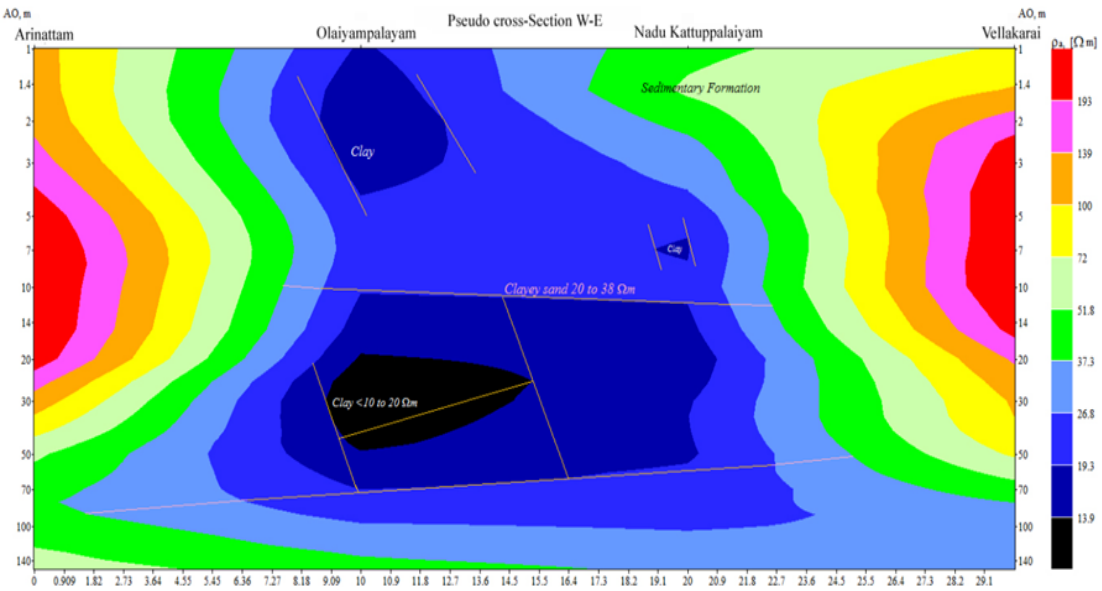

Fig. 4. Typical apparent resistivity curve and geoelectrical layer parameters as $K H, H A, Q A, K A$ types.

which implies the occurrence of saline water influvio marine sediments, flood basin, hornblende biotite gneiss, sandstone with clay and sandy limestone, which displays the presence of freshwater as indicated in northwest and southeast of the study area (Fig. 5c). Fourth layer resistivity value from 2.99 to $39774 \Omega \mathrm{m}$ was inferred in Tirvandipuram as low resistivity zone in saline sand and in Perperiyankuppam as higher resistivity in laterite with a thickness between 1.89 and 103 $\mathrm{m}$ observed in locations Chinna pagandai and Poigai arasur was represented by prevailing fine mixed sandstone and clay (Fig. $5 d$ ). High resistivity values of $>200$ $\Omega$ indicated hard nature of groundwater and low resistivity of $<10 \Omega \mathrm{m}$ indicate mixing of the aquifer with saline water in the freshwater system (Parasnis, 1997).

\section{Histogram of the study area}

The resistivity of the topsoil range from 14 to $119 \Omega \mathrm{m}$, with a thickness between 0.29 and $3.70 \mathrm{~m}$ (Table 4 and Fig. 6a,b). In the second layer, clay with limestone, sandstone and marine sediments were standard with resistivity values from 1.21 to $2533 \Omega \mathrm{m}$ with an average thickness of $5.73 \mathrm{~m}$. Second layer was demarcated as shallow aquifer (Quaternary and Pliocene - Tertiary aquifers) due to the occurrence of litho units to indicate as shale and clay, gravels, sandy limestone and tidal flat deposits (Gopinath and Srinivasamoorthy, 2014; Gopinath et al., 2017; Devaraj et al., 2018). Low resistivity $(0.27 \Omega \mathrm{m})$ was observed at Tiruppappuliyur and higher resistivity (39774 $\Omega \mathrm{m}$ ) observed in Perperiyankuppam both in the eastern and southern part of basin. Higher resistivity value outlines aquifer zones free from, pollution and a low resistivity value $(0.27 \Omega \mathrm{m})$ signifies the saline pollution of formation (Parasnis, 1997).

The third layer resistivity range between 0.27 and 1585 $\Omega \mathrm{m}$ with an average thickness of $22.23 \mathrm{~m}$, representing the occurrence of flood basin/back swamp deposits and sandstone, clay deposits, finely mixed with marine sand. The fourth and fifth layer identified inthe aquifer system with resistivity values between 2.99 to $39774 \Omega$ $\mathrm{m}$, respectively. Higher resistivity observed in locations Perperiyankuppam (39774 $\Omega \mathrm{m}$ ) signifies uncontaminated lateritic aquifer and low resistivity ranges $(2.99 \Omega \mathrm{m}$ and $2.13 \Omega \mathrm{m}$ ) in locations Tiruvendipuram and Panikankuppam indicates the dominance of saline water and clay (Richardson, 1992).

\section{Conclusion}

The study was performed by vertical electrical sounding to delineate salinity and freshwater along the contact zone of hard rock and sedimentary area in the study 
Ravi, R. et al. / J. Appl. \& Nat. Sci. 13(1): 268 - 277 (2021)
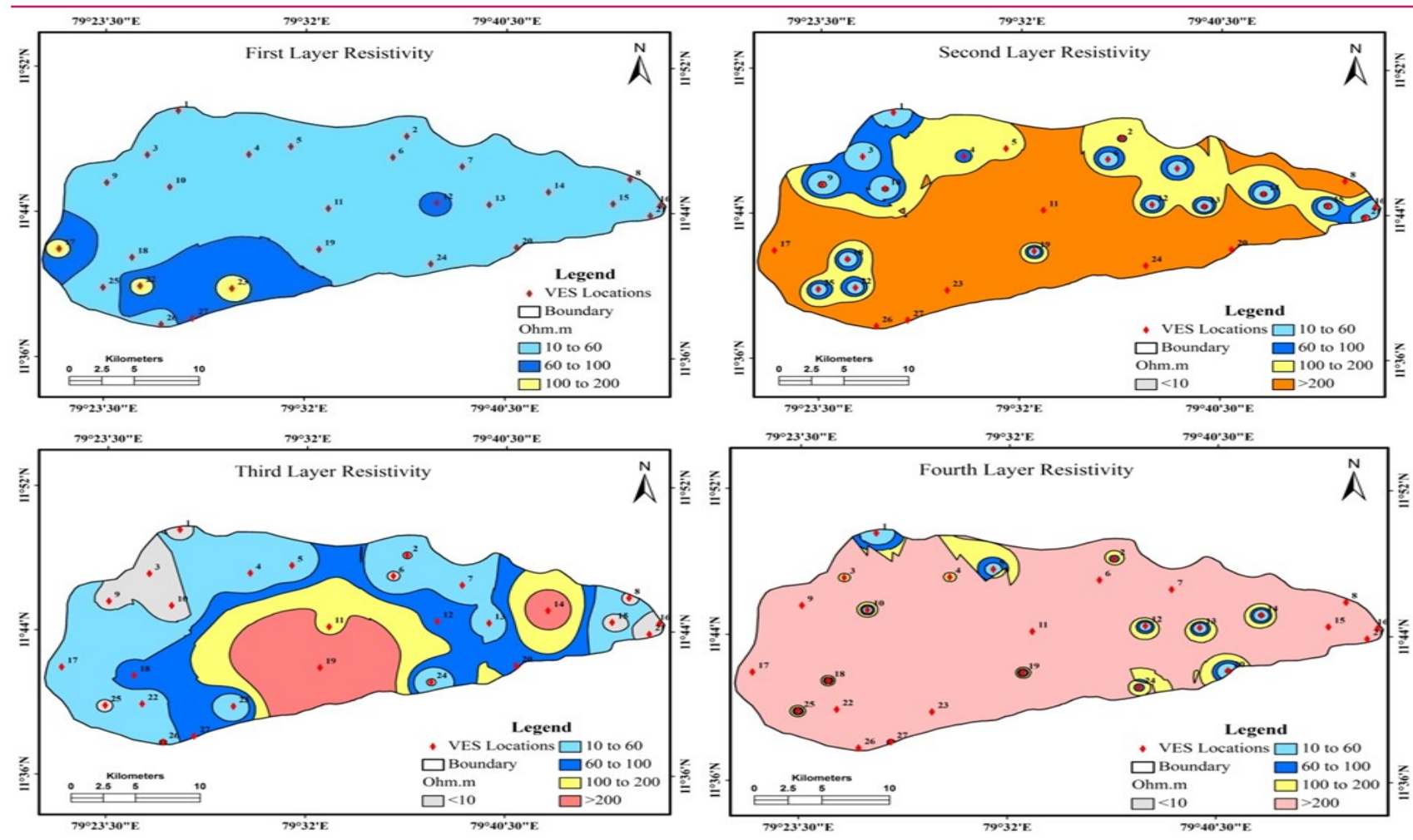

Fig. 5. Spatial distribution of four-layer Resistivity a) first layer resistivity in $\Omega m$, b) second layer resistivity $(\Omega m)$, c) third layer resistivity $(\Omega m)$, d) fourth layer resistivity $(\Omega m)$.

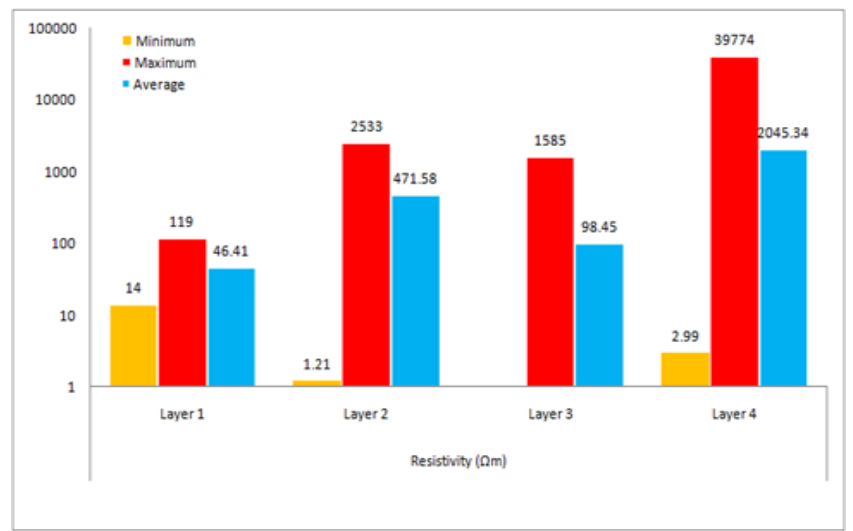

Fig. 6a. Resistivity ranges of the layer showing the minimum, maximum and average values.

area indicated that existing water was directly related to recharge from rivers and canals. In the VES data, $25.93 \%$ of the basin indicate $\mathrm{QH}$ type curve as $\rho 1>\rho 2>\rho 3>\rho 4>\rho 5>\rho 6<\rho 7,14.81 \%$ of the area represented descending-ascending $\mathrm{H}$ type to indicate $\rho 1>\rho 2<\rho 3>\rho 4$ and $14.81 \%$ by $\mathrm{HA}$ type as $\rho 1>\rho 2<\rho 3<\rho 4,11.11$ in the basin $\mathrm{KH}$ type indicated $\rho 1<\rho 2<\rho 3,7.41 \%$ by $\mathrm{KA}, \mathrm{AH}$ and $\mathrm{QA}$ types curve $\rho 1<\rho 2, \rho 1<\rho 2$, and $\rho 1>\rho 2$ and $3.70 \%$ by $A, Q$ and $K Q$ type curve as $\rho 1<\rho 2, \rho 1>\rho 2$ and $\rho 1<\rho 2$ types, respectively. Pseudo cross sections at depth delineate extractable water from the aquifers; might lead to saline water ingress below shallow depth. In coast high resistivity of $39774 \Omega \mathrm{m}$ was observed inthe south and low

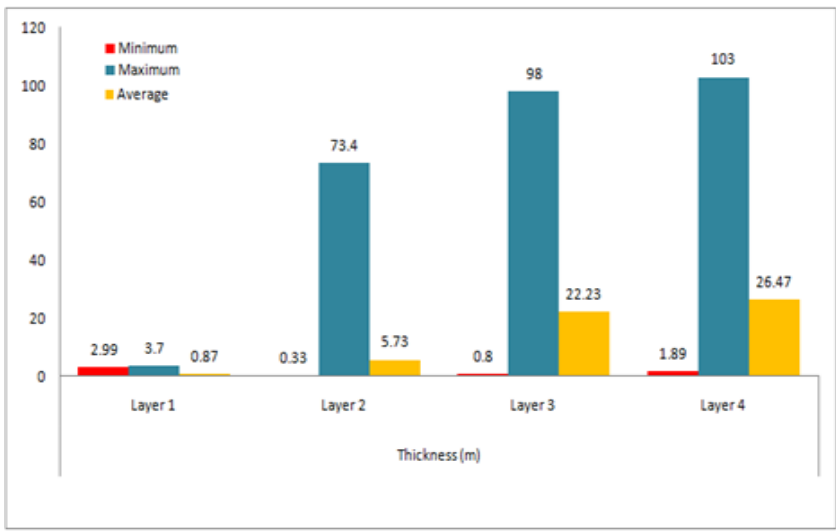

Fig. 6b. Thickness ranges of the layer showing the minimum, maximum and average values.

resistivity values $(0.27 \Omega \mathrm{m})$ were confined tothe east of the basin near the coast. The higher resistivity $>200 \Omega$ $\mathrm{m}$ and less resistivity of $<10 \Omega \mathrm{m}$ indicate the interaction of aquifers due to saline water ingress into the freshwater system and rock water pollution in the southern and western part. Resistivity of the first layer-top soil range from 14 to $119 \Omega \mathrm{m}$, with thickness between 0.29 and $3.70 \mathrm{~m}$. Second layer, resistivity values from 1.21 to $2533 \Omega \mathrm{m}$ with thickness range from 0.33 to $73.40 \mathrm{~m}$. Third layer resistivity values from 0.27 to $1585 \Omega \mathrm{m}$ with thickness range from 0.80 and $98 \mathrm{~m}$. Fourth layer resistivity values from 2.99 to $39774 \Omega \mathrm{m}$ with a thickness range between 1.89 and $103 \mathrm{~m}$. Maximum thickness and resistivity occurre in the above layer to indicate the 
Ravi, R. et al. / J. Appl. \& Nat. Sci. 13(1): 268 - 277 (2021)

consolidation of sediments and oxidation as laterites. Spatial resistivity maps signifying along east and north part of the basin where saline water was found to occur from the second layer and extende upto fourth layer might be due to inappropriate with drawal of groundwater from the shallow aquifer and due to occurrence of salinity adjacent to the coast. In other locations in the northwestern and eastern parts of the basin, the higher resistivity range indicate the presence of alkalis in the contact zone and fresh subsurface water movement inthe tertiary aquifer. This area may be categorized as good subsurface in the groundwater potential zone with a low resistivity value above $10 \Omega \mathrm{m}$ adjacent to the coast and in the middle part of this sedimentary aquifer to confirm its occurrence in coastal and tertiary aquifers.

\section{ACKNOWLEDGEMENTS}

I am thankful to Professor and Head, Dept. of Earth Sciences, to carry out the research project. I am grateful to my guide and research scholars in the Department of Earth Sciences, Annamalai University, for helping me for fieldwork in the resistivity meter reading and during resistivity investigation.

\section{Conflict of interest}

The authors declare that they have no conflict of interest.

\section{REFERENCES}

1. Al-Amri, M. (1996). The application of geoelectrical surveys in delineating groundwater in semiarid terrain case history from central Arabian Shield, M.E.R.C. Ain Shams Univ Earth Sci Sur, 10, 41-52.

2. Alile, O.M., Ujuambi, O., and Evbuomwan, I.A. (2011). Geoelectric investigation of groundwater in ObaretinIyanornon Locality, Edo State, Nigeria. J. Geol. Min. Res. 3(1), 13-20.

3. Aravindan, S., Manivel, M., and Chandrasekar, S.V.N. (2004). Groundwater quality in the hard rock area of the Gadilam river basin, Tamilnadu. Journal of Geological Society of India.63, 625-635.

4. Balasubramanian, A., Sharma, K.K., and Sastri, J.C.V. (1985). Geoelectrical and hydro geochemical evaluation of Coastal aquifers of Tambraparni basin, Tamilnadu. Geophys Res Bull 23, 203-209.

5. Bayewua, O.O., Oloruntola, M.O., Mosuro, G.O., Laniyan, T.A., Ariyo, S.O., and Fatoba, J.O. (2018). Assessment of groundwater prospect and aquifer protective capacity using resistivity method in Olabisi Onabanjo University campus, Ago-Iwoye, Southwestern Nigeria. NRIAG Journal of Astronomy and Geophysics, 7, 347-360. https:// doi.org/10.1016/j.nrjag.2018.05.002

6. Bethrand Ekwundu Oguama., Johnson Cletus Ibuot., and Daniel Nnaemeka Obiora. (2020). Geohydraulic study of aquifer characteristics in parts of Enugu North Local Government Area of Enugu State using electrical resistivity soundings. Applied Water Science, 10, 120. https:// doi.org/10.1007/s13201-020-01206-2

7. Biswas, A., and Sharma, S.P. (2016). Integrated geophysical studies to elicit the subsurface structures associated with uranium mineralization around South Purulia Shear Zone, India: a review. Ore GeolRev 72, 1307-1326.

8. Bobachev, A., Modin, I., and Shevnin, V. (2003). IPI2WIN, User's manual, programs set for 1-D VES data interpretation. Department of Geophysics, Geological Faculty, Moscow University, Russia.

9. CGWB (2015). Report on Pilot project on aquifer mapping in Lower Vellar watershed, Cuddalore district, Tamilnadu, Central Ground Water Board (CGWB).

10. Chakravarthi, V., Shankar, G.B.K., Muralidharan, D., Harinarayana, T., and Sundararajan, N. (2007). An integrated geophysical approach for imaging sub-basalt sedimentary basins: case study of Jam River basin, India. Geophysics, 72(6), B141-B147.

11. Custodio, E. (1997). Studying, monitoring and controlling seawater intrusion in coastal aquifers. In: Guidelines for study, monitoring and control. FAO water reports no. 11: FAO, Rome, pp 7-23.

12. Deepa, S., Venkateswaran, S., Ayyandurai, R., Kannan, R., and Vijay Prabhu, M. (2016). Groundwater recharge potential zones mapping in upper Manimuktha Sub basin Vellar river Tamil Nadu India using GIS and remote sensing techniques. Model. Earth Syst. Environ., 2, 137 DOI 10.1007/s40808-016-0192-9

13. Devaraj, N., Chidambaram, S., Panda, B., Thivya, C., Thilagavathi, R., and Ganesh, N. (2018). Geo-electrical approach to determine the lithological contact and groundwater quality along the KT boundary of Tamilnadu, India. Model Earth Syst Environ., 4, 269-279. https://doi.or $\mathrm{g} / 10.1007 / \mathrm{s} 4080$ 8-018-0424-2

14. Ekanem, A.M. (2020). Georesistivity modelling and appraisal of soil water retention capacity in Akwa Ibom State University main campus and its environs, Southern Nigeria. Modeling Earth Systems and Environment. Doi.org/10.1007/s40808-020-00850-6

15. Eyankware, M.O., Ogwah, C., and Selemo, A.O.I. (2020). Geoelectrical Parameters for the Estimation of Groundwater Potential in Fracture Aquifer at Sub-Urban Area of Abakaliki, SE Nigeria. Int J Earth Sci Geophy.s, 6, 031. DOI: $10.35840 / 2631-5033 / 1831$

16. Ezeh, C.C. (2011). Geoelectrical studies for estimating aquifer hydraulic properties in Enugu state. Niger Int $J$ Phys Sci., 6(14):3319-3329.

17. Frohlich, R.K., Urish, D.W., Fuller, J., and Reilly, M.O. (1994). Use of geoelectrical method in ground water pollution surveys in a coastal environment. J Appl Geophys 32, 139-154.

18. Gautam Param, K., and Biswas Arkoprovo. (2016). 2D Geo-electrical imaging for shallow depth investigation in Doon Valley Sub-Himalaya, Uttarakhand, India. Modeling Earth Systems and Environment, 2(4), 1-9. https:// doi.org/10.1007/s40808-016-0225-4

19. George, N.J., Akpan, A.E., and Akpan, F.S. (2017). Assessment of spatial distribution of porosity and aquifer geohydraulic parameters in parts of the tertiary-quaternary hydrogeoresource of south-eastern Nigeria. NRIAG $J$ Astron Geophys., 6(2), 422-433.

20. Ginsberg, A., and Levanton, A. (1976). Determination of saltwater interface by electrical resistivity sounding. Hydrol 
Sci Bull 21, 561-568.

21. Gopinath, S., and Srinivasamoorthy, K. (2014). Geophysical VES approach for seawater intrusion assessment in Nagapattinam and Karaikal coastal aquifers, India. Coastal resources and management strategies through spatial technology, Iyal Publications, India, pp 50-56.

22. Gopinath, S., Srinivasamoorthy, K., Saravanan, K., and Prakash, R. (2018). Discriminating groundwater salinization processes in coastal aquifers of southeastern India: geophysical, hydrogeochemical and numerical modeling approach. Environ Sustain. Dev., Doi: 10.1007/s1068-018 -0143-x

23. Gopinath, S., Srinivasamoorthy, K., Saravanan, K., Suma, C.S., Prakash, R., Senthinathan, D., and Sarma, V.S. (2017). Vertical electrical sounding for mapping saline water intrusion in coastal aquifers of Nagapattinam and Karaikal, South India. Sustain. Water Resour. Manag. DOI 10.1007/s40899-017-0178-4

24. Gopinath, S., Srinivasamoorthy, K., Saravanan, K., Suma, C.S., Prakash, R., Senthinathan, D., Chandrasekaran, N., Srinivas, Y., and Sarma, V.S. (2015). Modeling saline water intrusion in Nagapattinam coastal aquifers, Tamilnadu, India. Model. Earth Syst. Environ., 2:2 DOI 10.1007/ s40808-015-0058-6

25. Hussain, Y., Ullah, S.F., Akhter, G., and Aslam, A.Q. (2017). Groundwater quality evaluation by electrical resistivity method for optimized tube well site selection in an ago-stressed Thal Doab Aquifer in Pakistan. Model Earth Syst Environ., 3(1), 15.

26. Hussain, Y., Ullah, S.F., Dilawar, A., Akhter, G., MartinezCarvajal, H., and Roig, H.L. (2016). Assessment of the pollution potential of an aquifer from surface contaminants in a geographic information system: a case study of Pakistan. Geo Chicago 2016. Sustain. Resil. Geotech. Eng., doi:10.1061/9780784480120.063

27. Ibuot, J.C., Okeke, F.N., George, N.J., and Obiora, D.N. (2017). Geophysical and physicochemical characterization of organic waste contamination of hydrolithofacies in the coastal dumpsite of Akwa Ibom State, Southern Nigeria. Water Sci Tech-W Sup., 17(6), 1626-1637.

28. Jagadeeswara Rao, P., Rao Suryaprakasa., Rao Jagannadha., and Harikrishna, P. (2003). Geoelectrical data analysis to demarcate groundwater pockets and recharge zone in Champavathi river basin, Vixianagaram district, Andhra Pradesh. J Ind Geophy, 7(2), 105-113.

29. Kalinski, R.J., Kelly, W.E., and Bogardi, S. (1993). Combined use of geoelectrical sounding and profiling to quantify aquifer protection properties. Ground Water, 31, 538544.

30. Kayode, J., Adelusi, A., Nawawi, M., Bawallah, M., and Olowolafe, T. (2016). Geoelectrical investigation of near surface conductive structures suitable for groundwater accumulation in a resistive crystalline basement environment: a case study of Isuada, southwestern Nigeria. JAfr Earth Sci., 119:289-302.
31. Kopsiaftis, G., Mantoglou, A., and Giannoulopoulos, P. (2009). Variable density coastal aquifer models with application to an aquifer on Thira Island. Desalination, 237, 6580.

32. Lashkaripour, G.R. (2003). An investigation of groundwater condition by geoelectrical resistivity method: a case study in Korin aquifer, Southeast Iran. J Spatl, Hydrol, 3 (1), 1-5.

33. Mehmood, Z., Khan, N.M., Sadiq, S., Mandokhail, S., Ullah, J., and Ashiq, S.Z. (2020). Assessment of subsurface lithology, groundwater depth, and quality of UET Lahore, Pakistan, using electrical resistivity method. Arabian Journal of Geosciences, 13(6). https://doi.org/10.10 07/s12517-020-5260-9

34. Nejad Hadi Tahmasbi., Hoseini Fatemeh Zakeri., Mumipour Mehdi., KaboliAbdolreza., and Najib Morteza. (2012). Delineation of the Aquifer in the Curin Basin, south of Zahedan city, Iran. Open GeolJ 6:1-6.

35. Oguama, B.E., Ibuot, J.C., Obiora, D.N., and Aka, M.U. (2019). Geophysical investigation of groundwater potential, aquifer parameters, and vulnerability: a case study of Enugu State College of Education (Technical). Model Earth Syst Environ 5,1123-1133. https: //doi.org/10.1007/ s4080 8-019-00595 -x

36. Parasnis, D.S. (1997). Principles of Applied Geophysics. 5th Edition, Chapman and Hall, London, 104-176.

37. Prasanna, M.V., Cidambaram, S., Nagarajan, R., Rajalingam, S., and Elayaraja, A. (2009). Geophysical investigation in the different litho units of Gadilam river basin, Tamil Nadu, India. In book: Recent trend in Water Research: Hydrochemical and Hydrological perspectives Publisher: I.K International Publishing group Pvt. Ltd. India.

38. Richardson, D.L. (1992). Hydrogeological and Analysis of the Ground Water flow system of the Eastern Shore, Virginia. U.S. Geological Survey Open-File Report 91- 940, 117 pp.

39. Sholichin, Moh., and Tri Budi Prayogo. (2019). Field identification of groundwater potential zone by VES method in South malang, Indonesia. International Journal of Civil Engineering and Technology (IJCIET). Volume 10, Issue 02, pp. 999-1009, Article ID: IJCIET_10_02_097.

40. Subramanian, K.S., and Selvan, T.A. $(\overline{2001})$. Geology of Tamil Nadu and Pondicherry. Geological Society of India, Bangalore, pp.7-19.

41. Todd, D.K., and Mays, L.W. (2005). Groundwater hydrology, 3rd edn. Wiley, Hoboken.

42. Waswa, Aaron K., Christopher, M., Nyamai., Eliud Mathu., Daniel, W., and Ichang'i. (2015). Application of Magnetic Survey in the Investigation of Iron Ore Deposits and Shear Zone Delineation: Case Study of Mutomo-lkutha Area, SE Kenya. International Journal of Geosciences, 6, 729-740. http://dx.doi.org/10.4236/ijg.2015.67059

43. Zohdy, A.A.R., Eaton, G.P., and Mabey, D.R. (1974). Applications of surface geophysics to groundwater investigations. Techn. Water Resour. Investig US Geol. Surv., 2116 